\title{
PARASITE ENZYMES AS A TOOL TO INVESTIGATE IMMUNE RESPONSES
}

\section{ITALO M. CESARI; ISABELLE BOUTY*; DANIEL BOUT*; BELKISYOLÉ ALARCÓN DE NOYA** \& JOHAN HOEBEKE}

\begin{abstract}
Laboratorio de Immunoparasitología, Instituto Venezolano de Investigaciones Científicas, I.V.I.C., Apartado Postal 21827, Caracas 1020-A, Venezuela *Unité de Recherche Université - INRA d'Immunologie Parasitaire, UFR des Sciences Pharmaceutiques, 2 bis, Bd. Tonnellé, 37042 Tours Cedex, France * Laboratorio de Biohelmintiasis, Instituto de Medicina Tropical, Universidad Central de Venezuela (U.C.V.), Caracas, Venezuela *** Laboratoire des Protides des Liquides Biologiques, Faculté de Médicine, Université de Tours, 2 bis, Bd. Tonnellé, 37042 Tours Cedex, France
\end{abstract}

Previous evidences reported by us and by other authors revealed the presence of $\operatorname{Ig} G$ in sera of Schistosoma mansoni-infected patients to immunodominant antigens which are enzymes. Besides their immunological interest as possible inductors of protection, several of these enzyme antigens might be also interesting markers of infection in antibody-detecting immunocapture assays which use the intrinsic catalytic property of these antigens. It was thus thought important to define some enzymatic and immunological characteristics of these molecules to better exploit their use as antigens. Four different enzymes from adult worms were partially characterized in their biochemical properties and susceptibility to react with antibodies of infected patients, namely alkaline phosphatase (AKP, $\mathrm{Mg}^{2+}, \mathrm{pH}$ 9.5), type I phosphodiesterase (PDE, $\mathrm{pH}$ 9.5), cysteine proteinase (CP, dithiothreitol, $p H$ 5.5) and $N$-acetyl- $\beta$-D-glucosaminidase (NAG, $p H$ 5.5). The AKP and PDE are distinct tegumental membrane-bound enzymes whereas $C P$ and $N A G$ are soluble acid enzymes. Antibodies in infected human sera differed in their capacity to react with and to inhibit these enzyme antigens. Possibly, the specificity of the antibodies related to the extent of homology between the parasite and the host enzyme might be in part responsible for the above differences. The results are also discussed in view of the possible functional importance of these enzymes.

Key words: Schistosoma mansoni - antigenic enzymes - immunodiagnosis - alkaline phosphatase - type I phosphodiesterase - cysteine proteinase $-\mathrm{N}$-acetyl- $\beta$-D-glucosaminidase

An important part of the antibody response against schistosomes is directed against released excretory and secretory (ES) antigens (Lewis \& Strand, 1991). A certain proportion of ES antigens have been found to be parasite enzymes (Cesari et al., 1987; Cesari, 1990). Moreover, a few antigenic enzymes of Schistosoma mansoni have been used in experimental immunoprophylaxis studies (Bout et al.,

The present work was in part supported by "Fondation pour la Recherche Médicale" and "Région Centre (France)".

Abbreviations: 5'-adenosine monophosphate (5'-AMP), glucose-6-phosphate (G6P), $\beta$-glycerophosphate ( $\beta G P$ ), p-nitrophenyl phosphate (pNPP), 4-methylumbelliferyl phosphate (4-MUP), L-cysteine (L-Cys), L-phenylalanine (L-Phe), adenosine triphosphate (ATP), ethylenediaminetetraacetic acid (EDTA), sodium dodecyl sulfate (SDS), N-carbobenzoxy- (CBZ-), arginine (Arg), 7-amido-4-methylcoumarin (AMC).
1978; Balloul et al., 1987) or as tools for immunodiagnosis (Pujol et al., 1989; Chappell et al., 1989, 1990).

Using an antibody-detecting solid phase immunocapture assay that exploit the intrinsic catalytic property of enzyme antigens, it was shown previously that sera of most $S$. mansoniinfected human individuals from venezuelan endemic regions exhibit IgG antibodies against the Alkaline Phosphatase (AKP) of adult worms (Pujol et al., 1989).

The AKP of adult schistosomes is an integral membrane-bound glycoprotein that catalyzes dephosphorylation of nucleotide and sugar monophosphate esters. It has a tetrameric structure of molecular mass $260 \mathrm{kD}$ (Cesari et al., 1981; Payares et al., 1984) and has been visualized with a specific anti-S. mansoni AKP monoclonal antibody by immunofluorescence 
in the tegument of adult worms (Pujol et al., 1990) where it might play an important role in the nutritional exchanges of sugars, nucleotides and phosphates (Cesari et al., 1981; Cesari, 1985). In vitro, the AKP has been found associated with small vesicles shedded probably from the tegumental surface of apparently undamaged adult worms (Cegarra Casas, 1987); possibly, this turnover mechanism might operate also in vivo and for this reason circulating anti-AKP antibodies are found in infected hosts (Pujol et al., 1989).

Type I Phosphodiesterase (PDE) is another integral glycoprotein component of the adult worm tegumental surface membrane which probably shares the same molecular microenvironment with AKP (Cesari et al., 1981; Pujol, 1985). Like AKP, this enzyme is also found in vitro associated with small membranous vesicles (Cegarra Casas, 1987); it is immunogenic in natural infections and of possible interest for immunodiagnosis (Cesari et al., 1987, 1991).

Soluble haemoglobin and protein-degrading cysteine proteinases (CP) have been suggested to be present in the intestine of adult schistosomes (Dresden \& Deelder, 1979; Chappell \& Dresden, 1986, 1987; Zerda et al., 1988). Haemoglobinase and a cathepsin B similar to the mammalian lysosomal cysteine proteinase enter probably the host circulation upon periodical regurgitation of the gut content by adults (Lawrence, 1973; Chappell \& Dresden, 1986; Klinkert et al., 1989). These enzymes have been shown to react by werstern blot, dot blot and ELISA with sera from infected patients and have been proposed as putative serodiagnostic reagents for the detection of schistosome infections (Ruppel et al., 1985a, b; Klinkert et al., 1989; Chappell et al., 1989, 1990).

$N$-acetyl- $\beta$-D-glucosaminidase (NAG), a soluble lysosomal enzyme in most species, is described here for the first time and, like CP, it is present in acid $S$. mansoni adult worm extracts. This enzyme hydrolyzes substrates containing 2-acetamido-2-deoxy-D-glucosamine and its role in $S$. mansoni or in the hostparasite relationship has to be yet investigated. Preliminary evidences on its natural immunogenicity in some infected patients are forwarded in this study.

The present work was devised to make a comparative assessment of the human anti- parasite enzyme antibody responses to the above four enzyme systems by using immunocapture assays similar to APIA and enzyme inhibition assays in the presence of antibodies. Results suggest the immunogenicity of these enzymes in natural infections, confirm the diagnostic potential of some of them, and show the existence of individual differences in antienzyme responses that may be genetically restricted and possibly related to the degree of homology between the parasite (non self) and the host (self) enzymes. The study contributes also to the knowledge of the anti-parasite immune status in infected patients.

\section{MATERIALS AND METHODS}

Sera - A small group of 32 sera from $S$. mansoni-infected venezuelan and another of 11 from $S$. mansoni-infected african patients were used in the present study. The infected patients from the venezuelan endemic region exhibited low intensities of infection (less than $100 \mathrm{eggs} / \mathrm{g}$ faeces) and were all positive for the circumoval precipitin (COP) test (data not shown). The infected african patients were from Mali and were found positive for $S$. mansoni after rectal biopsy examination; sera from these patients were kindly given to us by $\mathrm{Dr} D$. Richard-Lenoble, Department of Parasitology, University of Tours, France. Ten negative healthy patients from non endemic regions were also included in this study.

Parasite extracts - Lyophilized adult worms of the venezuelan JL $S$. mansoni strain were homogenized with a teflon pestle in $0.5 \mathrm{M}$ sucrose, $1 \mathrm{mM} \mathrm{MgCl}$ and $10 \mathrm{mM}$ phosphate buffer $\mathrm{pH}$ 7.2. The homogenate was centrifuged at $8 \times 10^{6} \mathrm{~g}$-min at $4{ }^{\circ} \mathrm{C}$. The soluble fraction was processed for acid extraction as described below, whereas the pellet was resuspended in $1 \mathrm{mM} \mathrm{MgCl}$ and $50 \mathrm{mM}$ Tris/ $\mathrm{HCl}$ buffer $\mathrm{pH} 8.0$, recentrifuged, resuspended in the same buffer and recentrifuged under the same conditions. Butanolic extract (BE) was prepared essentially as described by Pujol et al. (1989) by resuspending the pellet in a small buffer volume and stirring for $15 \mathrm{~min}$ at $37^{\circ} \mathrm{C}$ with an equal volume of water-saturated $n$ butanol. After centrifugation at $2 \times 10^{5} \mathrm{~g}$-min at $4{ }^{\circ} \mathrm{C}$, the aqueous phase was recovered and dialyzed against $50 \mathrm{mM}$ tris/ $\mathrm{HCl}$ buffer $\mathrm{pH} 7.2$ containing $0.15 \mathrm{M} \mathrm{NaCl}$ (TBS) and $1 \mathrm{mM}$ $\mathrm{MgCl}_{2}$. After dialysis, membrane-derived glycoprotein components (alkaline phosphatase, phosphodiesterase) were solubilized and stabi- 
lized by addition of $0.1 \%(\mathrm{w} / \mathrm{v})$ Triton X-100 and glycerol up to $20 \%$. The soluble fraction from the homogenate was dialyzed overnight at $4{ }^{\circ} \mathrm{C}$ against $0.5 \mathrm{mM} \mathrm{HgCl}, 1 \mathrm{mM}$ EDTA and $200 \mathrm{mM} \mathrm{NaCl}$ (Barrett \& Kirschke, 1981; Moreau et al., 1988). The precipitated proteins were removed by centrifugation at $2 \times 10^{5} \mathrm{~g}$ $\mathrm{min} / 4^{\circ} \mathrm{C}$ and the acid extract (AE) containing soluble enzymes (cysteine proteinases, $\mathrm{N}$ acetyl- $\beta$-D-glucosaminidase) conserved at -20 ${ }^{\circ} \mathrm{C}$ until use.

Protein assays - The protein content of each parasite preparation was determined by the Bradford methodology (1976) using the Coomassie Plus Protein Assay Reagent of Pierce (Rockford, IL, USA) and bovine serum albumin as a standard.

Enzyme assays - End-point chromogenic microassays $(50 \mu \mathrm{l}$ in wells of a microtiter plate) were routinely conducted in triplicate at $37^{\circ} \mathrm{C}$ as follows. For AKP, about $0.5-1.0 \mu \mathrm{g}$ of $\mathrm{BE}$ protein was assayed in $50 \mathrm{mM}$ diethanolamine buffer $\mathrm{pH} 9.5$ containing $1 \mathrm{mM}$ $\mathrm{MgCl}_{2}, 0.1 \mathrm{mM}$ EDTA and $1 \mathrm{mM} p$-nitrophenyl phosphate. For type I PDE, the BE was incubated in the same buffer containing $1 \mathrm{mM}$ thymidine-5'-monophospho-p-nitrophenyl ester. Proteolytic activity was maximal by testing $0.5-1.0 \mu \mathrm{g}$ of AE protein in $50 \mathrm{mM}$ phosphate buffer $\mathrm{pH} 5.5$ in the presence of $2 \mathrm{mM}$ dithiothreitol (DTT) and $1 \mathrm{mM} \mathrm{CBZ-Phe-Arg-}$ p-nitroanilide; cysteine proteinases $(C P)$ responsible for these activities were preactivated by incubation $\left(15 \mathrm{~min}\right.$ at $0^{\circ} \mathrm{C}$ ) with DTT before substrate addition. For NAG, AE was incubated in $50 \mathrm{mM}$ tris-maleate buffer $\mathrm{pH} 5.5$ and $1 \mathrm{mM} p$-nitrophenyl $\mathrm{N}$-acetyl- $\beta$-D-glucosaminide. At the end of the incubation period, AKP, PDE and NAG reactions were stopped by adding $50 \mu \mathrm{l} /$ well of $1 \mathrm{~N} \mathrm{NaOH} ; \mathrm{CP}$ was stopped by adding the same amount of $0.1 \mathrm{M}$ Na-chloroacetate in $0.1 \mathrm{M}$ acetate buffer $\mathrm{pH}$ 4.0. The amounts of protein in the assays were adjusted by dilution such that the absorbancy at $405 \mathrm{~nm}$ of the released chromogens fell within the linear range of the standard $p$ nitrophenol and $p$-nitroaniline calibrating curves. Products of reaction were measured in a Titertek Multiskan MCC/340 MK II (Flow Laboratories, VA, USA). One unit (U) of activity was defined as the amount of enzyme needed to liberate $1 \mu \mathrm{mol}$ of chromogen per minute under the respective above assay conditions.
Enzyme inhibition assays - The IgG fraction from various infected sera was obtained by adding ammonium sulfate up to $33 \%$ saturation to the sera, centrifuging at $2 \times 10^{5} \mathrm{~g}$ min at $4{ }^{\circ} \mathrm{C}$ and resuspending the pellet in PBS at the original volume. Enzyme activities were evaluated as described above in the presence of $10 \%(\mathrm{v} / \mathrm{v})$ seric IgG fraction (about $30 \mu \mathrm{g}$ of IgG protein in the assay). Higher IgG concentrations were also tested in AKP assays.

Parasite enzyme immunocapture assays Evaluation of circulating anti-enzyme antibodies in chosen sera was done essentially with the solid phase assay developed by Pujol et al. (1989) (Fig. 1). Briefly, Dynatech Immulon-2 microtiter plates were sensitized with $50 \mu \mathrm{l}$ $(0.5 \mu \mathrm{g})$ of Protein $\mathrm{A}$ in $0.05 \mathrm{M}$ carbonatebicarbonate buffer $\mathrm{pH} 9.6$ per well; the wells were then saturated for $30 \mathrm{~min}$ at $37^{\circ} \mathrm{C}$ with $1 \%(\mathrm{w} / \mathrm{v})$ casein in $0.1 \mathrm{M}$ carbonate-bicarbonate buffer $\mathrm{pH}$ 10.0. Immune and control sera were diluted 1:100 in TBS and $50 \mu$ added to their respective wells so as to allow immobilization of IgG by Protein A. Washings of other serum components (including host enzymes) were done with TBS containing $0.05 \%(v / v)$ Tween 20 (TBS-Tween). Saturation of all antibodies sites in the wells was done by incubating with $50 \mu \mathrm{l} /$ well excess crude parasite antigen (BE for the alkaline activities, $\mathrm{AE}$ for the acid ones). Removal of unbound antigens was done by washing with TBS-Tween and immunocaptured enzyme was revealed by adding $50 \mu \mathrm{l} /$ well of specific enzyme substrate solution. When colour development was sufficiently discriminative, $50 \mu \mathrm{l} /$ well of cold water was added to the wells and the plate read at $405 \mathrm{~nm}$ in Multiskan. For each enzymatic systm tested, an initial checkerboard experiment was done to know optimal immunoassay conditions and the minimal amount (in $50 \mu \mathrm{l} /$ well) of enzyme $(\mathrm{mU} / \mathrm{ml})$ needed to saturate all specific antibody binding sites. At least 15 $\mathrm{mU} / \mathrm{ml}$ were needed for the AKP immunoassay (APIA) and $30 \mathrm{mU} / \mathrm{ml}$ for the PDE on (PDIA). CP and NAG immunoassays (CPIA, NAGIA) were tried using $10-12 \mathrm{mU} / \mathrm{ml}$. In all the above assays, blank values obtained in the absence of serum were substracted from all the values and the serum sample exhibiting immunocaptured enzyme activity higher than the cut-off value (established by adding three standard deviations to the mean activity shown by control sera), was considered as positive. 
Immunocaptured $\mathrm{CP}$ was also detected by a kinetic fluorescent assay in sensitized Dynatech Microfluor B plates using $0.1 \mathrm{mM}$ CBZ-Phe-Arg-AMC in $0.1 \%$ Brij and $50 \mathrm{mM}$ phosphate buffer $\mathrm{pH} 5.5$; readings were done at fixed time intervals up to $80 \mathrm{~min}$ in a Microfluor reader (Dynatech, Alexandria, VA, USA). A quantitative expression of the results could be given by calculating the rate of fluorescence increase since this parameter is directly related to the amount of enzyme captured. The rate was calculated by simple regression and the amount of released fluorescence from a standard curve for AMC.

Statistical analysis - The data were evaluated by simple regression analysis or ANOVA non parametric analysis.

\section{RESULTS}

Immunocapture of $\mathrm{S}$. mansoni alkaline phosphohydrolases - A summary of some bio- chemical features of the S. mansoni Alkaline Phosphatase (AKP) and Type I Phosphodiesterase (PDE) activities are presented in Tables I and II. They allow to characterize and to distinguish between these two enzyme systems.

About $90 \%$ of the venezuelan $S$. mansoniinfected patient sera tested were positive by APIA (Fig. 2A), in agreement with what had been reported previously (Pujol et al., 1989; Cesari et al., 1991); the APIA values of these sera were significantly different from those exhibited by the control sera. On the other hand, about 7 out of the 11 african sera tested were positive for APIA (Fig. 2A).

After APIA evaluation (1-2 $\mathrm{h}$ incubation after substrate addition), the products of the AKP reaction were washed away from the wells and the chromogenic substrate for PDE added (Fig. 1). PDIA needed about $10 \mathrm{~h}$ incubation at $37{ }^{\circ} \mathrm{C}$ for colour development due to its slower enzymatic reaction and to the lower

\section{TABLE I}

Summary of some biochemical features of adult Schistosoma mansoni Alkaline Phosphatase

$\begin{array}{ll}\text { Specificity } & \text { catalyzes removal of phosphate from: } \\ & \text { * nucleotides monophosphates (5'-AMP) } \\ & \text { * phosphorylated sugars (G6P, } \beta \mathrm{GP}) \\ & \text { synthetic substrates (p-NPP, 4-MUP) } \\ & \text { stimulators: } \mathrm{MgCl}_{2} \text { (non essential activator), } \mathrm{KCl}, \mathrm{CsCl} \text {, glycerol, Triton } \mathrm{X}-100 \\ \text { Effectors } & \text { inhibitors: } \mathrm{L}-\mathrm{Cys}, \mathrm{L}-\mathrm{Phe}, \mathrm{ZnCl}_{2}, \mathrm{CaCl}{ }_{2}, \mathrm{EDTA}, \mathrm{ATP}, \text { molybdate } \\ \text { Molecular Mass } & 260 \mathrm{kD} \text { (tetramer; active), } 130 \mathrm{kD} \text { (dimer; active), } 65 \mathrm{kD} \text { (4 equal inactive subunits) } \\ \text { Other features } & \text { membrane-bound integral } \mathrm{glycoprotein}, \text { extractable with n-butanol, solubilized with } 1 \% \\ & \text { Triton X-100, thermostable } \\ \text { References } & \text { Ernst, } 1977 \text {; Cesari et al., } 1981 \text {; Payares et al., 1984; Cesari et al., in preparation }\end{array}$

TABLE II

Summary of some biochemical features of adult Schistosoma mansoni Alkaline Type I Phosphodiesterase

Specificity

Effectors

Molecular Mass

Other features catalyzes the hydrolysis of thymidine S'-monophosphate $p$-nitrophenyl ester

stimulators: $\mathrm{MgCl}_{2}, \mathrm{CaCl}_{2}$

inhibitors: L-Cys, SDS

not yet known .

membrane-bound integral glycoprotein, extractable with n-butanol, solubilized with $1 \%$ Triton X-100, thermostable, not recognized by the 2BSC7 anti-S. mansoni AKP monoclonal antibody 

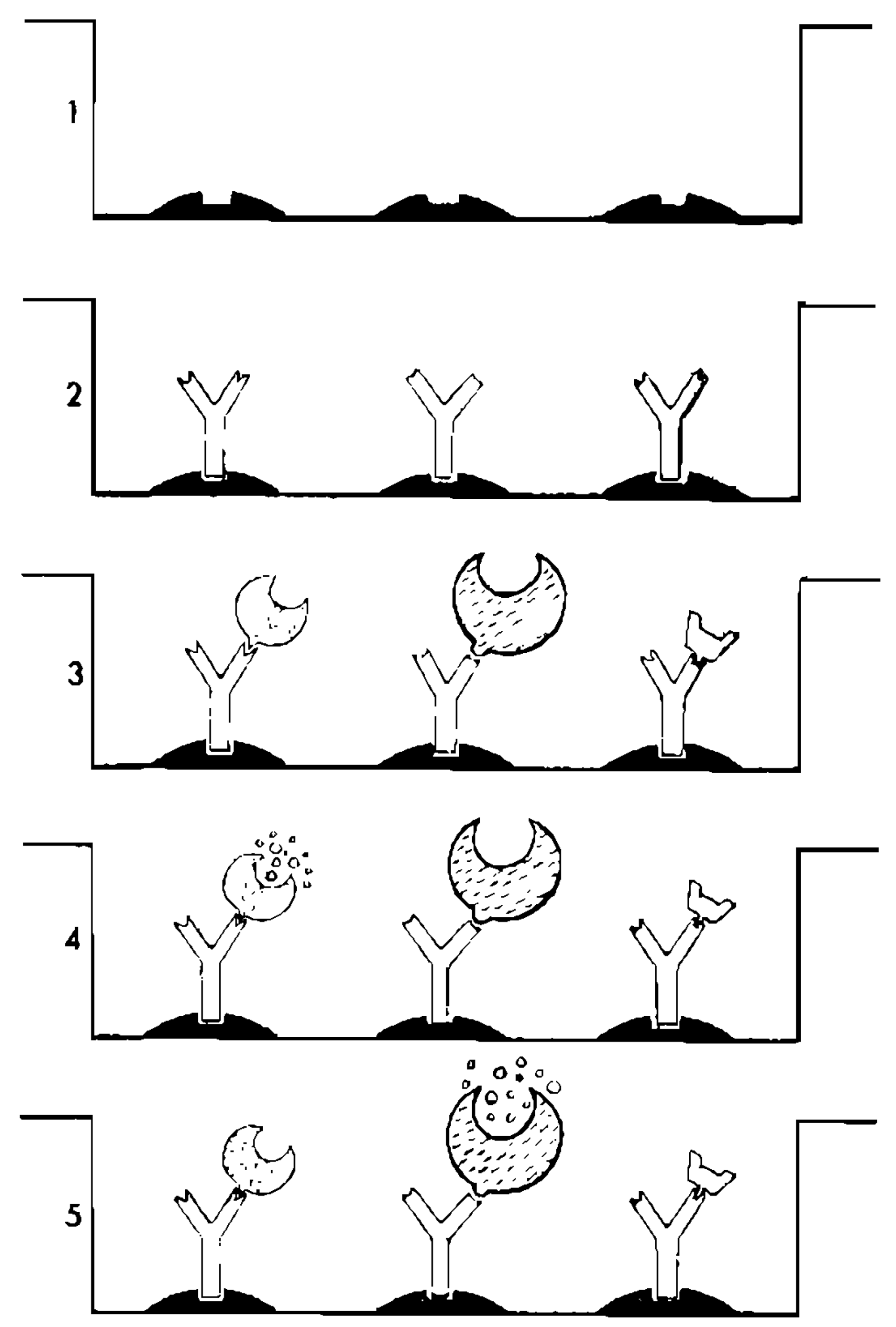

Fig. 1: parasite-enzyme immunocapture assay -1 . Microtiter plate well coated with Protein A $(0.5 \mu \mathrm{g} /$ well); 2. Immobilized IgG from diluted (1:100) serum; 3. IgG-mediated immunocapture of antigenic parasite enzymes from crude extracts; 4 . Evaluation of a first enzymatic reaction upon addition of specific substrate solution; 5. Subsequent evaluation of another enzymatic reaction after washing and addition of a second specific substrate solution. amount of captured enzyme in the wells (Cesari et al., 1981, 1987, 1991). About 87\% of the infected venezuelan patient sera showed definite presence of anti-PDE antibodies (Fig. 2B). On the other hand, 6 out of the 11 african sera were barely positive for PDIA (Fig. 2B). The PDIA values of the infected venezuelan patient sera were significantly different from those exhibited by african and control patient sera but no significant differences were found between the latter two groups of sera.

Preliminary results with sera from patients infected with other parasites (Plasmodium falciparum, Leishmania mexicana, Toxoplasma gondii, Toxocara canis, Ascaris lumbricoides, Taenia solis) indicate that they are negative in PDIA (data not shown).

A positive correlation $(p=0.01)$ was observed between APIA and PDIA values; however, some individuals clearly exhibited low anti-AKP response and high anti-PDE response, and viceversa (Fig. 3).

Immunocapture of S. mansoni acid hydrolases - A summary of some biochemical features of the Cysteine Proteinase (CP) and Nacetyl- $\beta$-D-glucosaminidase (NAG) activities found in the AE preparation are presented in Tables III and IV. The enzymes responsible for CP activity (Table III) hydrolyzed chromogenic or fluorogenic synthetic peptides at the carboxyl Arg; they required at least one more aminoacid, preferably Phe between the C-terminal Arg and the amino-blocking group (Table III).

TABLE III

Summary of some biochemical features of adult Schistosoma mansoni Acid Cysteine Proteinase Activities

Specificity

Kinetics

Substrate specificity

Effectors

Molecular Mass

Other features

References catalyzes the hydrolysis of CBZ-N-blocked synthetic peptides (endopeptidase)

$\mathrm{K}_{\mathrm{m}}=8.2 \mu \mathrm{M}$ with CBZ-Phe-Arg-p-nitroanilide

CBZ-Phe-Arg-derivatives > CBZ-Arg-Arg-derivatives

stimulators: L-Cys, dithiothreitol, Tween 20

inhibitors: $\mathrm{HgCl}_{2}$, heavy metals

$56,66 \mathrm{kD}$

extractable under acid conditions with $\mathrm{HgCl}_{2}$

Cesari et al., in preparation 

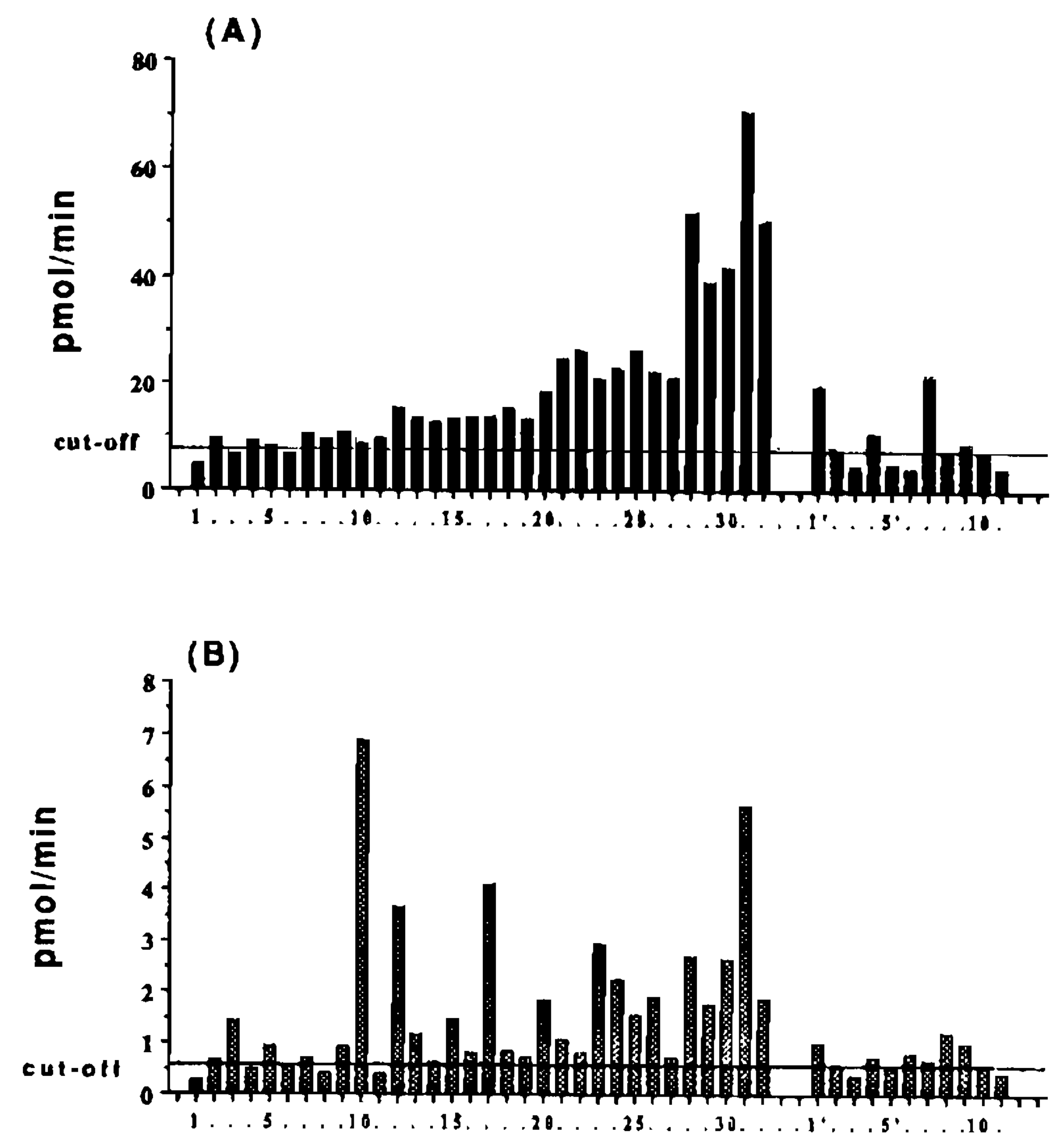

(C)

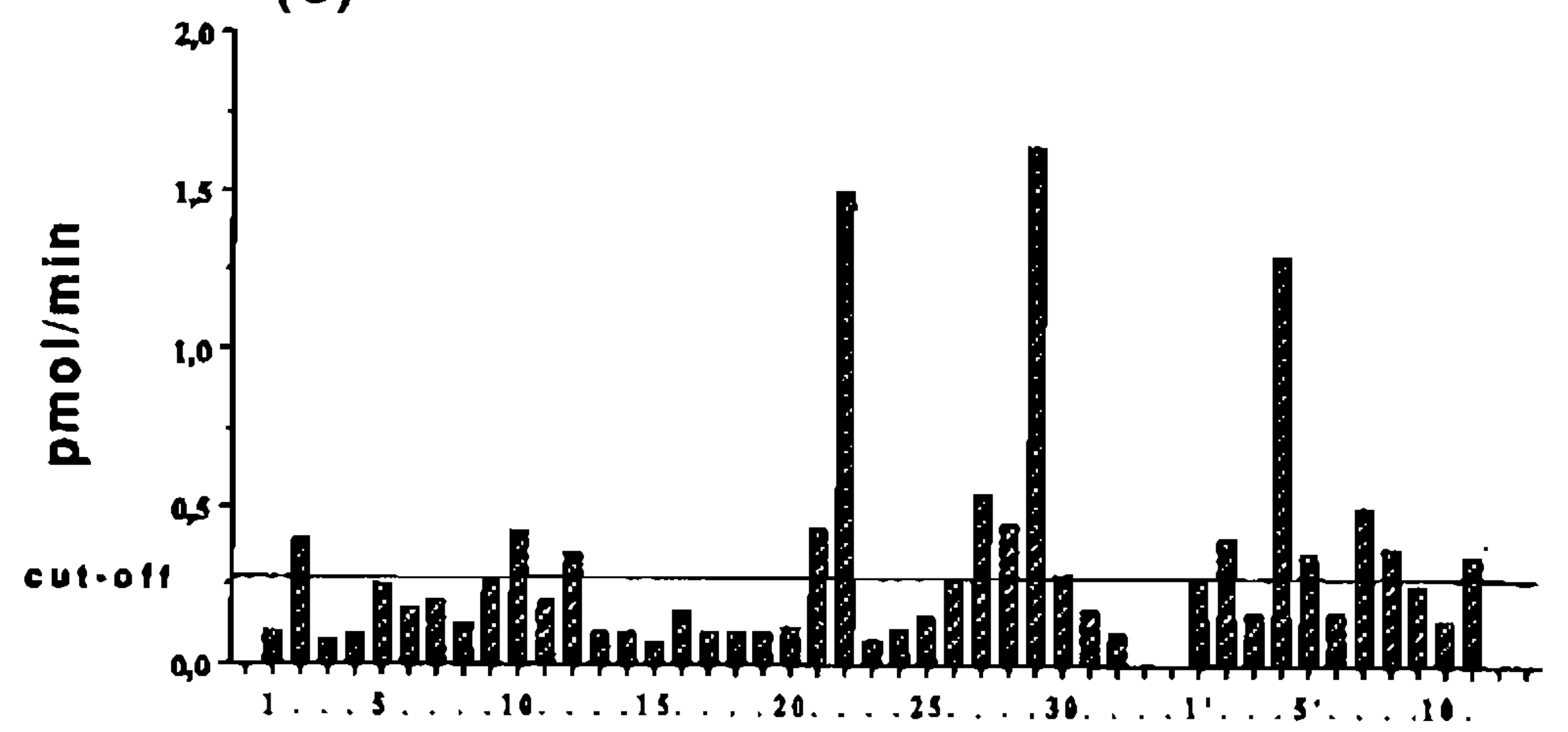

Fig. 2: parasite-enzyme immunocapture assays - 1-32: Schistosoma mansoni-infected venezuelan patients; 1'-1 1': $S$. mansoni-infected african (Mali) patients. The cut-off in each assay was established with 10 healthy donor patient sera. (A) APIA, cut-off $=6.9 \mathrm{pmol} / \mathrm{min}$; (B) PDIA, cut-off $=0.55 \mathrm{pmol} / \mathrm{min}$; (C) CPIA, cut-off $=0.27 \mathrm{pmol} / \mathrm{min}$.

Immunocapture assays analogous to APIA and PDIA were developed for CP (CPIA) and NAG (NAGIA) to assess antibody response to these enzymes in infected patients.

Detection of immunocaptured CP was difficult with the chromogenic substrate CBZ-
Phe-Arg- $p$-nitroanilide; the enzymatic reaction signal was very weak. However, the activity was clearly and rapidly seen with the fluorogenic substrate CBZ-Phe-Arg-AMC (Fig. $2 C$ ). Most sera were apparently negative by this test and no correlation could be found with APIA or PDIA (data not shown). Evalu- 


\section{TABLE IV}

Summary of some biochemical features of adult Schistosoma mansoni acid N-Acetyl- $\beta$-D-glucosaminidase

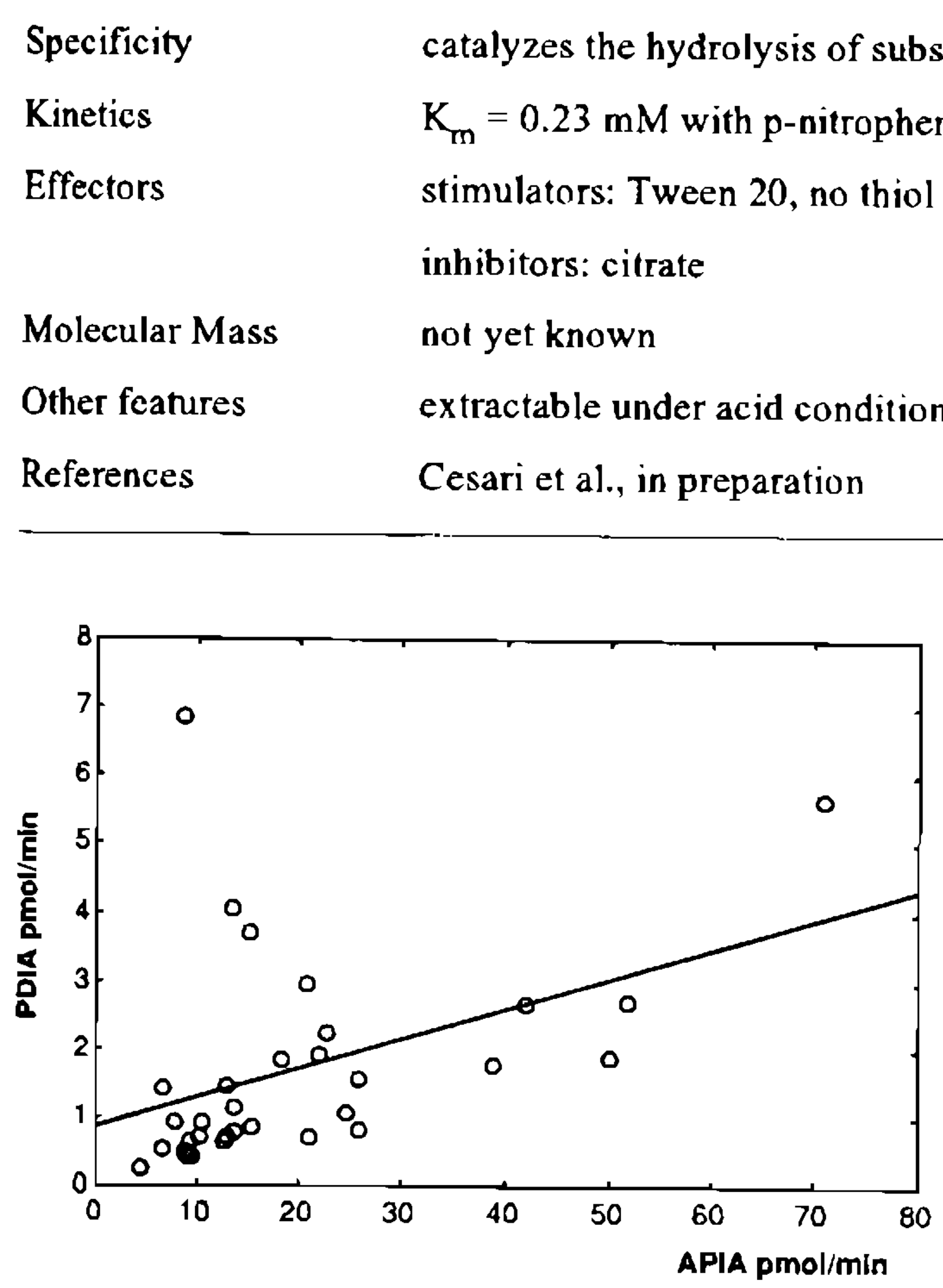

Fig. 3: correlation between APIA and PDIA - statistical analysis was done with the APIA and PDIA values obtained for the $32 S$. mansoni-infected venezuelan sera in Figs 2A, 2B.

ation of the specificity of the reaction with sera from patients infected with other parasites remains to be done.

NAGIA was tried with $p$-nitrophenyl Nacetyl- $\beta$-D-glucosaminide but, similarly to the CPIA, very weak signals were obtained after $24 \mathrm{~h}$ incubation with this chromogenic substrate (data not shown). Evaluation of NAGIA with a fluorogenic substrate is in progress.

Inhibition assays - The IgG serum fractio from ten $S$. mansoni infected patients, tested at $10 \%$ in the enzymatic assays, did not significantly inhibit the AKP activity of the $S$. mansoni $\mathrm{JL}$ adult worms (Fig. 4A); higher IgG concentrations (up to $50 \%$ in the assays) were not inhibitory either (data not shown). On the other hand, 7 out of $10 \mathrm{IgG}$ fractions exhibited inhibition on the PDE activity (Fig. 4B), 2/10 on the $\mathrm{CP}$ activity (Fig. $4 \mathrm{C}$ ) and $4 / 10$ on the NAG activity (Fig. 4D). Few individuals had simultaneous inhibition to more than one en-
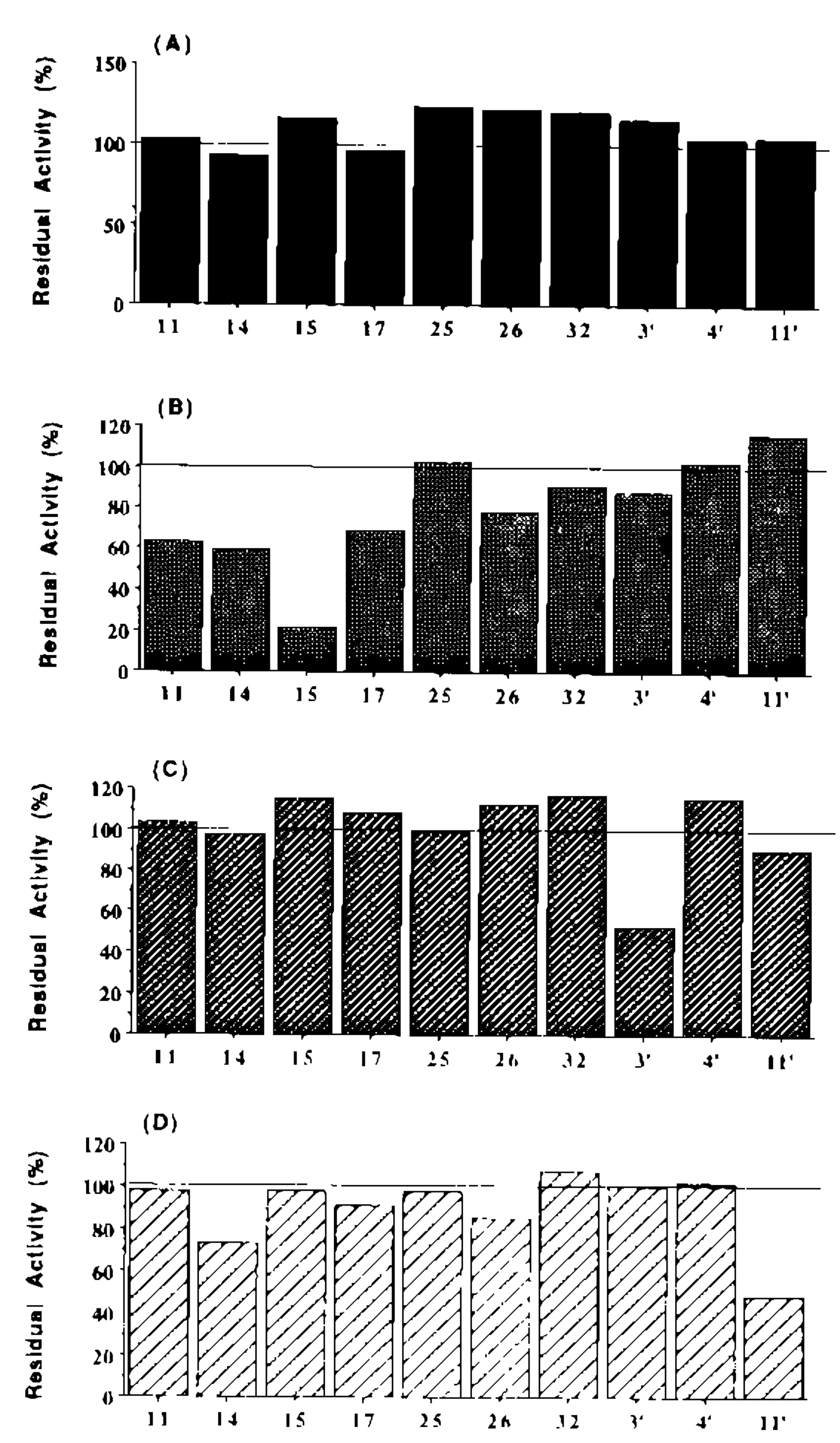

Fig. 4: inhibition enzyme assays - Assays were performed in the presence of $\mathrm{IgG}$ fractions at $10 \%$ from 10 different venezuelan and african Schistosoma mansoniinfected sera (patient sera number stated under each histogram). (A) effect of IgG on AKP; (B) effect of IgG on PDE; (C) effect of IgG on CP; (D) effect of IgG on NAG. Values are expressed as \% residual activity relative to the mean activity obtained in the presence of IgG fraction from normal sera. 
zyme (Fig. 4). Under the assay conditions used, the different IgG preparations did not show intrinsic AKP, PDE, CP or NAG activities (data not shown). IgG fractions from normal human sera did not significantly inhibit the above parasite activities and the mean value obtained with them was used as the $100 \%$ residual activity control (straight lines seen in Fig. 4). The degree of inhibition observed on PDE, CP and NAG activities varied among different patients and never went to completion. No definite enhancement of activity was appreciated for the above activities in the presence of the IgG preparations (Fig. 4).

\section{DISCUSSION}

Previously published results have shown that about $93 \%$ of $S$. mansoni-infected venezuelan patient sera possess anti-parasite alkaline phosphatase (AKP) antibodies as measured by the Alkaline Phosphatase Immunoassay (APIA). This parasite-enzyme immunocapture assay exhibited a remarkable $(100 \%)$ specificity based on crossed studies with sera from patients infected with other parasitic diseases and other schistosome species (Pujol et al., 1989; Cesari et al., this symposium). The anti-AKP response, as measured by APIA, did not correlate with sex, age, the clinical status of the patients or the intensity of the infection (Pujol et al., 1989; Cesari et al., 1991). Most of the APIA-positive individuals exhibited a low to moderate anti-AKP response, a few exhibiting high anti-AKP response (Fig. 2A; Pujol et al., 1989; Cesari et al., 1991). It was suggested that the individual genetic capacity to recognize and to respond to the parasite AKP seemed to play a role in this antigenantibody system (Pujol et al., 1989; Cesari et al., 1991).

In the present work, APIA results were obtained with a set of venezuelan sera different to those used in previous publications (Pujol et al., 1989; Cesari et al., 1991) and they further support our previous conclusions. Also, for the first time, a few african (Mali) $S$. mansoni-infected sera were tested by this assay (Fig. 2A); although the number of sera tested was low and the number of sera found positive were lower than expected as compared to the venezuelan sera, there appears to exist, however, cross-recognition of the southamerican JL $S$. mansoni AKP by some infected african patient sera (Fig. 2A).
The IgG fraction from a limited number (10) of venezuelan and african $S$. mansoniinfected patient sera did not significantly inhibited the parasite AKP activity (Fig. 4A). Preliminary surveys performed with a higher number of sera from infected patients, confirm that a significant human inhibitory response against the $S$. mansoni AKP does not seem to exist, suggesting that the corresponding polyclonal antibody responses are probably directed towards parasite-specific $B$ cell enzyme epitopes other than those related to the catalytic site. The inability of infected human sera to inhibit the parasite AKP was not related to antibody titers since higher concentrations of seric IgG in the assays did not significantly alter the activity and, probably, it may be related to the specificity of the antibodies. Earlier results indicated that there was no crossreaction between the $S$. mansoni and the C57BL/6 liver or intestinal AKP (Pujol \& Cesari, 1990). However, the $S$. mansoni AKP is susceptible to be inhibited by L-Phe (Table 1) like mammalian intestinal AKPs (McComb et al., 1979; Harris, 1982), suggesting that they probably share conserved regions for similar functioning. Probably, the degree of conserved functional homology existing between parasite and host AKP may influence the production of inhibitory and non inhibitory antibodies. Previous results have shown that purified IgG from sera of chronically $S$. mansoni-infected CBA mice significantly inhibited the parasite AKP by up to $25 \%$ (Cesari et al., 1981) and that sera from chronically infected C57BL/6 mice were able to inhibit it by up to $35-40 \%$ (Pujol, 1989) suggesting that the host genetic background, related (or not) to enzyme homology, is probably affecting this anti-enzyme immune response.

The antibody response to PDE, an enzyme present also in $\mathrm{BE}$, was analyzed in the same well subsequent to APIA by washing away the hydrolytic products of the AKP reaction and by adding the appropriate enzyme substrate solution. This was possible thanks to the avoidance of enzyme-denaturing reagent to stop the previous enzymatic reaction and to the independency of enzyme-antibody-complex formation in the well (Fig. 1).

$\mathrm{PDE}$ is a molecule different from AKP (Tables I, II) and affinity-purified AKP is devoid of PDE activity (unpublished data). The anti-PDE response, as measured by the Phosphodiesterase Immunoassay (PDIA; Fig. 2B), 
exhibited a certain degree of specificity and a positive correlation with APIA (Fig. 3), the two immunoassays detected more or less the same positive patients (Figs 2A, 2B, 3); however, some individuals responded relatively different to AKP and to PDE. This fact may allow an increase in diagnostic sensitivity when, for instance, negative or low APIA responders become positive for PDIA or viceversa.

Seven out of $10 \mathrm{IgG}$ preparations from $S$. mansoni-infected sera were able to inhibit the PDE reaction at different degree of intensity; in one case, inhibition reached $70 \%$ (Fig. 4B). Interestingly, the IgG fraction from pooled sera of experimentally infected CBA mice was not able to inhibit this activity (unpublished observations). PDE seems, thus, more susceptible than AKP to inhibition by human but not by mouse antibodies, probably for the same reasons discussed above in relation to the AKP inhibition.

Haemoglobin degradation takes place in the adult parasite gut thanks to the presence of haemoglobinases and cathepsin B (Timms \& Bueding, 1959; Dresden \& Deelder, 1979; Senft et al., 1980; Ruppel et al., 1985a; Lindquist et al., 1986; Chappell \& Dresden, 1986; Bogitsh \& Kirschner, 1986; Klinkert et al., 1989). Cysteine Proteinases (CP) may thus play a key survival role in the parasite nutrition and an effective immune response against them might have important implications in the development of resistance to schistosomiasis. The Cysteine Proteinase Immunoassay (CPIA) was performed in short-term kinetic assays with fluorescent substrate; few APIA- and/or PDIApositive patients were found positive by this assay (Fig. 2C). This could be due to one or several of the following reasons: a) a yet unoptimised solid phase assay making the anti$\mathrm{CP}$ response to appear variable among individuals; b) weak IgG anti-CP response in infected individuals, other isotypes being more relevant to this response; $c$ ) predominant presence of anti-CP inhibitory antibodies; this is unlikely since most $\mathrm{IgG}$ fractions from apparently CPIA-negative $S$. mansoni-infected individuals (Fig. 2) were unable to inhibit the $C P$ activity (Fig. 4C); d) progressive CP-mediated proteolysis of the immobilized IgG; e) a high degree of homology between the parasite and the individual host $\mathrm{CP}$; $f$ ) high immunocapture of $\dot{C} P$ by non specific antibodies in control sera (low CPIA specificity) and, consequently, elevated noise in these sera leading to a high cut-off value; this reason may be particularly relevant because of the low amounts of immunocaptured CP in the CPIA (Fig. 2C).

Concerning NAGIA, we have to wait results with the use of fluorescent substrate. In inhibition assays, four infected subjects were able to show anti-NAG inhibitory IgG response (Fig. 4D). It is worth to mention that NAG seems to play a major role in the regulation of the immune response in staphylococcal infections by interfering with the functions of immunocompetent cells (Valisena et al., 1991). Our preliminary results suggest that adult worms and eggs possess significant amounts of this enzyme; furthermore, preliminary experiments also have shown that NAG from eggs exhibits exactly the same pattern of inhibition as NAG from adults using the same IgG fractions. The immunity to NAG in natural infections seems, thus, to be confirmed.

Inhibiting as well as non inhibiting antienzyme antibodies are found in the same patient (Figs 2,4), reflecting the presence of an anti-parasite immune status. We do not know, however, to what extent this immune status is protective for the host. It might be protective if the antibodies would impair or neutralize the function of key parasite metabolic enzymes and/or if they would trigger the antibody-dependent effector mechanisms that have been described to kill parasites (Sher \& Colley, 1989). For instance, the inhibition of the $S$. mansoni $28 \mathrm{kDa}$ glutathione S-transferase (GST) activity by rat antibody reduces female worm fecundity and egg viability and thus disease pathology in experimental infections (Xu et al., 1991) supporting the basis for an anti-parasite vaccine. Consequently, the progressive antibody-mediated impairement of important parasite enzyme functions during infection or after vaccination might be relevant for the development of an anti-parasite immune resistance.

We might expect that antibodies would not be made against the active site regions of homologous parasite enzymes as they would represent self-epitopes. The catalytic site of enzymes is considered to be conserved during evolution and the presence of antibodies against it appears to be unlikely. Thus, when parasite enzyme functions are found more or less impaired by enzyme-inhibiting antibodies in infected hosts, we might assume that the im- 
mune response is directed against non self, parasite-specific epitopes related to the catalytic site; the enzyme under study may be specific for the parasite or may have a lower degree of homology with its host counterpart. However, the possibility exists that homologous parasite enzymes may induce an autoimmune response in some individuals and this eventuality should be carefully investigated for each enzymatic system under study.

In conclusion, results reported here (Figs 2, 4) suggest that infected patients produce an heterogeneous polyclonal antibody response against enzyme antigens that vary quantitatively and qualitatively from one individual to another and for a given enzyme antigen. In different infected hosts the amount of enzymes released from the worms may vary and cause differences in the individual antibody response to these enzymes. However, it seems quite probable that the differences in recognition and or response may depend more on the individual genetic background and the degree of homology between host and parasite enzyme.

The anti-enzyme response measured by immunocapture assays (mostly due to non-inhibitory IgG antibodies) (Fig. 2) did not necessarily match the pattern of the IgG-mediated inhibitory response (Figs 2, 4); however, the information obtained by both methodologies are complementary and they may contribute to the understanding of immunity against parasite enzyme antigens.

Studies on the structure of parasite enzymes and on the mechanisms of induction of the immune anti-enzyme responses may provide new, potent and specific diagnostic and/or vaccinating reagents as well as a better understanding of the host-parasite relationships, of immunoresistance mechanisms, and result in the development of new strategies for immunoprotection or pharmacological attack.

\section{ACKNOWLEDGEMENTS}

To Miss Lourdes Acuña for her technical assistance and the original drawings, and to Mrs Dany Tabareau for her helpful secretarial work.

\section{REFERENCES}

BALLOUL, J. M.; SONDERMEYER, P.; DREYER, D.; CAPRON, M.; GRZYCH, J. M.; PIERCE, R. J.;
CARVALLO, D.; LECOCQ, J. P. \& CAPRON, A., 1987. Molecular cloning of a protective antigen of schistosomes. Nature, 326: 149-153.

BARRETT, A. J. \& KIRSCHKE, H., 1981. Cathepsin B, cathepsin H, and cathepsin L. p. 535-560. In Methods in Enzymology, Vol. 80, Academic Press, New York.

BOGITSH, B. J. \& KIRSCHNER, K. F., 1986. Schistosoma mansoni: ultrastructural localization of a haemoglobinase using mercury-labeled pepstatin. Exp. Parasitol., 62: $211-215$.

BOUT, D.; DUPAS, H.; CAPRON, M.; EL GAZAWI, A.; CARLIER, Y.; DELACOURTE, A. \& CAPRON, A., 1978. Purification, immunochemical and biological characterization of malate dehydrogenase of Schistosoma mansoni. Immunochemistry, 5: 633 638.

BRADFORD, M. M., 1976. A rapid method for the quantitation of microgram quantities of protein utilizing the principle of protein-dye binding. Anal. Biochem., 72: 248-254.

CEGARRA CASAS, M., 1987. Análisis bioquímico y antigénico de extractos salinos y productos de excreción y secreción de vermes adultos de Schistosoma mansoni. Biol. Sci. Thesis. 114 p. Simón Bolívar University, Sartenejas, Caracas.

CESARI, I. M., 1985. El tegumento de Schistosoma mansoni y su importancia en la relación hospedadorparásito. Boletín de la Dirección de Malariología y Sanidad Ambiental, XXV: 27-41.

CESARI, 1. M., 1990. Components parasitarios de interés para el diagnóstico inmunológico de la esquistosomiasis mansoni. Interciencia, 15: 76-85.

CESARI, 1. M.; SIMPSON, A. J. G. \& EVANS, W. H., 1981. Properties of a series of tegumental membrar--bound phosphohydrolases of Schistosoma mansoni. Biochem. J., 198: 467-473.

CESARI, I. M.; PUJOL, F. H.; ALARCON DE NOYA, B.; NOYA, O.; HOEBEKE, J. \& BOUT, D., 1992. Immunodiagnosis based on enzyme markers, p. 83101. In R. Bergquist. Diagnostic Approaches in Schistosomiasis, John Wiley \& Sons.

CESARI, 1. M.; PUJOL, F. H.; RODRIGUEZ, M. \& ALARCON DE NOYA, B., 1987. Antigenic enzymes of Schistosoma mansoni: possible use for immunodiagnosis. Mem. Inst. Oswaldo Cruz, 82: 175-177.

CHAPPELL, C. L. \& DRESDEN, M. H., 1986. Schistosoma mansoni: proteinase activity of "haemoglobinase" from the digestive tract of adult worms. Exp. Parasitol., 61: 160-167.

CHAPPELL, C. L. \& DRESDEN, M. H., 1987. Purification of cysteine proteinases from adult Schistosoma mansoni. Arch. Biochem. Biophys., 256: 560-568.

CHAPPELL, C. L.; HACKEL, J. \& DAVIS, A. H., 1989. Cloned Schistosoma mansoni proteinase (haemoglobinase) as a putative serodiagnostic reagent. $J$. Clin. Microbiol., 27: 196-198.

CHAPPELL, C. L.; DRESDEN, M. H.; GRYSEELS, B. \& DEELDER, A. M., 1990. Antibody response to Schistosoma mansoni: adult worm cysteine proteinases in infected individuals. Am. J. Trop. Med. Hyg., 42: 335-341.

DRESDEN, M. H. \& DEELDER, A. M., 1979. Schistosoma mansoni: thiol proteinase properties 
of adult worm "haemoglobinase". Exp. Parasitol., 48: 190-197.

ERNST, S. C., 1977. Biochemical and cytochemical studies of alkaline phosphatase activity in Schistosoma mansoni. Rice University Studies, 62: $81-95$.

HARRIS, H., 1982. Multilocus enzyme systems and the evaluation of gene expression: the alkaline phosphatases as a model example. p. 95-124. In The Harvey Lectures. Series 76. Academic Press, New York.

KLINKERT, M-Q; FELLESEIN, R.; LINK, G.; RUPPEL, A. \& BECK, E., 1989. Primary structure of Sm 31/32 diagnostic proteins of Schistosoma mansoni and their identifications as proteases. Mol. Biochem. Parasitol., 33: 113-122.

LAWRENCE, J. D., 1973. The ingestion of red blood cells by Schistosoma mansoni. J. Parasitol., 59: 60-63.

LEWIS, S. A. \& STRAND, M., 1991. Characterization of proteins and immunogens released by adult Schistosoma mansoni. J. Parasitol., 77: 263-271.

LINDQUIST, R. N.; SENFT, A. W.; PETTIT, M. \& McKERROW, J., 1986. Schistosoma mansoni: purification and characterization of the major acid proteinase from adult worms. Exp. Parasitol, 60: 398-404.

McCOMB, R. B.; BOWERS, G. N., Jr. \& ROSEN, S. 1979. Alkaline phosphatases. Plenum Press, New York.

MOREAU, T.; ESNARD, F.; GUTMAN, N.; DEGAND, P. \& GAUTHIER, F., 1988. Cysteine-proteinaseinhibiting function of $\mathrm{T}$ kininogen and of its proteolytic fragments. Eur. J. Biochem., 173: 185-190.

PAYARES, G.; SMITHERS, S. R. \& EVANS, W. H., 1984. Purification and topographical location of tegumental alkaline phosphatase from adult Schistosoma mansoni. Mol. Biochem. Parasitol., 13: 343-360.

PUJOL, F. H., 1985. Aislamiento de una fracción de la membrana de superficie del verme adulto de Schistosoma mansoni. M. Sc. Thesis, I.V.I.C., Caracas.

PUJOL, F. H., 1989. Evaluación de la fosfatasa alcalina y otros antígenos para el diagnóstico inmunológico de la esquistosomiasis mansoni, mediante el uso de anticuerpos policlonales y monoclonales. $\mathrm{Ph}$. Sc. Thesis, I.V.I.C., Caracas.
PUJOL, F. H. \& CESARI, 1. M., 1990. Antigenicity of adult Schistosoma mansoni alkaline phosphatase. Parasite Immunology, 12: 189-198.

PUJOL, F. H.; ALARCON DE NOYA, B. \& CESARI, I. M., 1989. Immunodiagnosis of schistosomiasis mansoni with APIA (Alkaline Phosphatase Immunoassay). Immunological Investigations, 18: 1071-1080.

PUJOL, F. H.; LIPRANDI, F.; RODRIGUES, M., \& CESARI, I. M., 1990. Production of a mouse monoclonal antibody against the alkaline phosphatase of adult Schistosoma mansoni. Mol. Biochem. Parasitol., 40: 43-52.

RUPPEL, A.; ROTHER, U.; VONGERICHTEN, H.; LUCIUS, R. \& DIESFELD, H. J., 1985a. Schistosoma mansoni: immunoblot analysis of adult worm proteins. Exp. Parasitol., 60: 195-206.

RUPPEL, A.; DIESFELD, H. J. \& ROTHER, U., 1985 b. Immunoblot analysis of Schistosoma mansoni antigens with sera of schistosomiasis patients: diagnostic potential of an adult schistosome polypeptide. Clin. Exp. Immunol., 62: 499-506.

SENFT, A. W.; GOLDBERG, M. W.; BYRAM, J. E. \& JAVIAN, J. S., 1980. Schistosomal haemoglobinase: nature of the protease and implications for the host. p. 427-442. In H. Van den Bossche, The Host Parasite Interplay. Elsevier North-Holland Biomedical Press, Amsterdam.

SHER, A. \& COLLEY, D. G., 1989. Immunoparasitology. p. 957-979. In W. E. Paul, Fundamental Immunology. Raven Press, New York.

TIMMS, A. R \& BUEDING, E., 1959. Studies of a proteolytic enzyme from Schistosoma mansoni. Brit. J. Pharmacol., 14: 68-73.

VALISENA, S.; VARALDO, P. E. \& SETTA, G., 1991. Staphylococcal endo- $\beta-N$-acetylglucosaminidase inhibits responses of human lymphocytes to mitogens and interferes with production of antibodies in mice. J. Clin. Invest., 87: 1969-1976.

ZERDA, K. S.; DRESDEN, M. H. \& CHAPPELL, C. L., 1988. Schistosoma mdnsoni: expression and role of cysteine proteinases in developing schistosomula. Exp. Parasitol., 67: 238-246.

XU, C-B.; VERWAERDE, C.; GRZYCH, J-M.; FONTAINE, J. \& CAPRON, A., 1991. A monoclonal antibody blocking the Schistosoma mansoni 28-kDa glutathione transferase activity reduces female worm fecundity and egg viability. Eur. $J$. Immunol., 21: 1081-1807. 